\title{
Thoracoepigastric flap for the closure of an elbow defect in an intravenous drug abuser: A case report and review of literature
}

\author{
Chenicheri Balakrishnan MD, Matthew J Bonanno MD, Nayiri D Scaff MD
}

\begin{abstract}
C Balakrishnan, MJ Bonanno, ND Scaff. Thoracoepigastric flap for the closure of an elbow defect in an intravenous drug abuser: A case report and review of literature. Can J Plast Surg 2003;11(2):83-84.

The reconstruction of large soft tissue defects of the upper extremity is a challenging problem. Although free tissue transfer in a single stage is preferred, the recipient blood vessels usually determine the outcome. Due to venous occlusion from repeated intravenous drug abuse, the use of a thoracoepigastric flap to cover a complex wound of the elbow is reported.
\end{abstract}

Key Words: Thoracoepigastric flap

\section{Un lambeau thoracoépigastrique pour fermer une anomalie du coude chez une personne qui abusait des drogues intraveineuses : Un rapport de cas et une analyse bibliographique}

\begin{abstract}
La reconstruction d'importantes anomalies des tissus mous de l'extrémité supérieure représente un défi. Bien que le transfert de tissus libres en une seule étape soit préconisé, les vaisseaux sanguins du receveur déterminent généralement l'issue. En raison d'une occlusion veineuse causée par l'usage répété de drogues intraveineuses, l'utilisation d'un lambeau thoracoépigastrique pour fermer une blessure complexe du coude est présentée.
\end{abstract}

$\mathrm{R}$ econstruction of soft tissue defects of the upper extremity Rin intravenous drug abusing patients is a challenging problem. Although a single stage reconstruction with free tissue transfer is routinely used, the lack of healthy veins in the intravenous drug user make these procedures technically impossible. Flaps from the chest, abdomen and groin could be fashioned to close upper extremity defects in stages. The deep inferior epigastric system has an abundance of musculocutaneous perforators and communicates with the intercostal arteries and superficial system of axial vessels of the groin. The purpose of the present report is to evaluate the use of a flap based on the epigastric system to cover a defect of the elbow, where a single stage reconstruction of the defect was not feasible due the underlying disease.

\section{CASE PRESENTATION}

A thirty-seven-year-old man who had sustained a close range gunshot wound to the right elbow presented with a significant soft tissue defect of the proximal forearm, over the lateral aspect. He had a long history of intravenous drug use and infective endocarditis. Venous access was difficult in any of the extremities. Because there were fractures of the radius and ulna, including the humeroulnar joint, he underwent open reduction and internal fixation. The hardware could not be covered with local tissue (Figure 1).

Because free tissue transfer was not feasible, a decision was made to cover the defect using a thoracoepigastric flap based on the communication between the deep inferior epigastric system and the lower intercostals. The flap was elevated and the donor site closed primarily. The flap was inset over the defect (Figure 2) and the upper extremity was immobilized using an abdominal binder. The flap was divided at 18 days (Figure 3). The fracture went on to heal without complications.

\section{DISCUSSION}

The epigastric vascular system links the subclavian and external iliac arteries. Studies carried out on the angiosomes have helped reconstructive surgeons design flaps based on patients' blood supply. The skin of the chest and abdominal wall are supplied by a number of perforator vessels. The deep epigastric arcade forms the abdominal portion of a ventral vascular network linking the subclavian and external iliac arteries. This network forms the basis of various axial flaps used in reconstructive surgery. In 1937, Webster (1) described a thoracoepigastric flap extending from the axilla to the groin. This flap was designed on a vascular axis, the abdominal component being the superficial inferior epigastric and superficial circumflex iliac arteries. This concept was used for the unipedicled open or tubed flaps (2). The internal mammary and deep epigastric system supplies the transverse medially based flaps by means of a longitudinal series of perforating vessels. Studies have also shown that the deep inferior epigastric artery is more significant in supplying the skin of the anterior abdominal wall. There is communication between the epigastric system and the intercostal arteries. This enables a large oblique skin flap to be elevated from the abdomen $(3,4)$. This can be used as a free flap with a reduced muscle component or as a perfora-

Department of Plastic Surgery, Wayne State School of Medicine, Detroit, Michigan, USA.

Correspondence and reprints: Dr C Balakrishnan, Associate Professor of Surgery, Department of Plastic Surgery, Wayne State University, 4201 St. Antoine, Detroit, Michigan 48201, USA. Telephone 313-745-3008, fax 313-745-3214, e-mail cbalakri@med.wayne.edu 


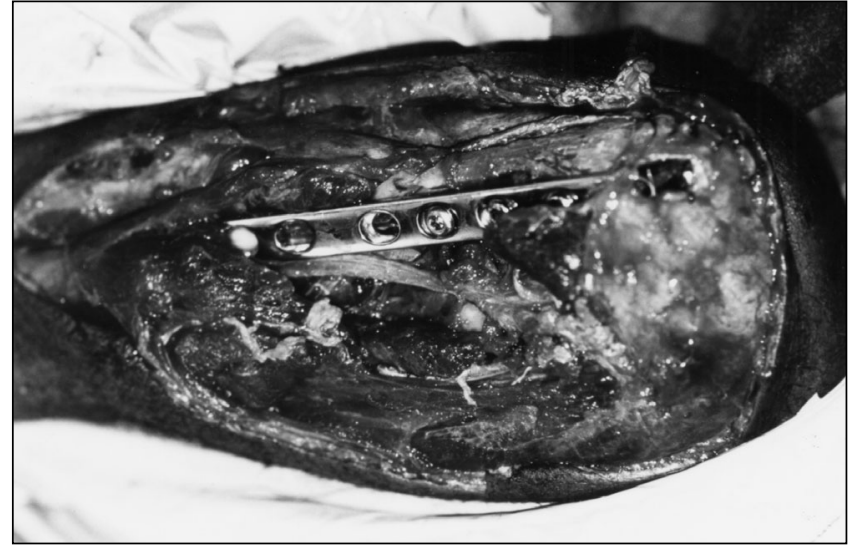

Figure 1) A soft tissue defect of the elbow with an exposed fixation plate

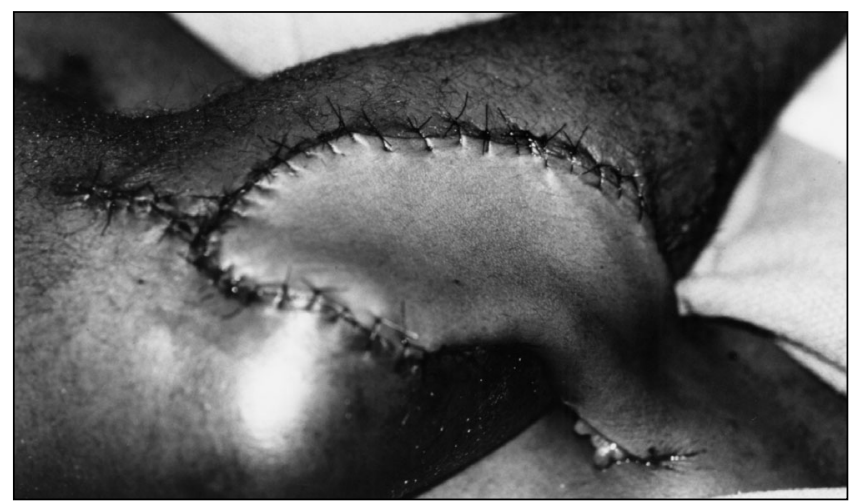

Figure 2) Thoracoepigastric flap covering the defect

\section{REFERENCES}

1. Webster JP. The thoraco-epigastric tubed pedicles. Surg Clin North Am 1937;17:145.

2. Didolkar MS, Baff RR, Bakamjian VY. Use of a tubed thoracoepigastric flap to cover the defect from a hindquarter amputation: Case report. Plast Reconstr Surg 1978;61:112-4.

3. Boyd JB, Taylor IG, Corlett R. The vascular territories of the superior epigastric and deep inferior epigastric systems. Plast Reconstr Surg 1984;73:1-14.

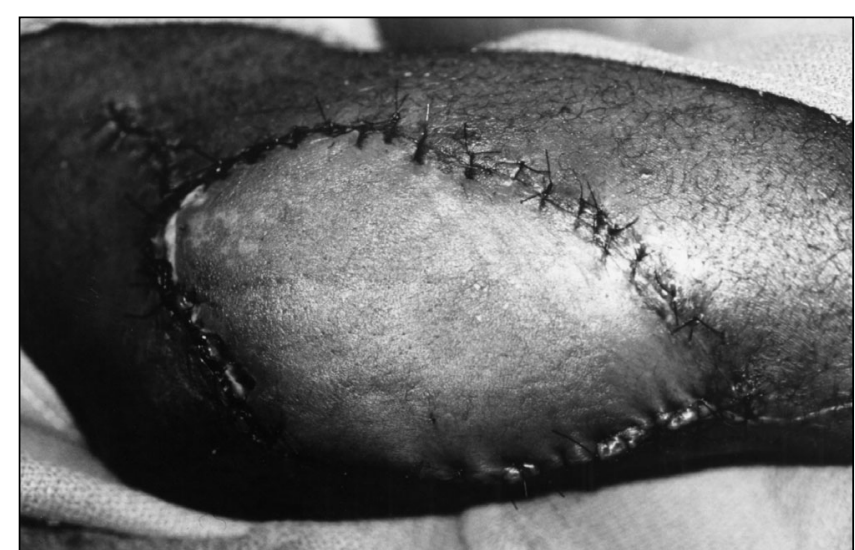

Figure 3) Division of the flap 18 days following surgery

tor based flap, by carefully dissecting the artery and a few selected perforators. The reliability of this flap allows the flap to be extended well beyond the posterior axillary line. The donor site can be closed or, in thin individuals, split skin grafted. The flap can be expanded to obtain a larger cutaneous surface area; it improves vascularity and induces a fibrous capsule that augments the abdominal wall and permits primary closure of the donor site (5).

The cutaneous vascular territory of the deep inferior epigastric system, in communication with the intercostal arteries, enables a large oblique ellipse of skin to be elevated. This can be used to resurface extensive skin defects of the adjacent arm (6).

4. Taylor GI, Corlett R, Boyd JB. The versatile deep inferior epigastric (inferior rectus abdominis) flap. Br J Plast Surg 1984;37:330-50.

5. Schaeffer CS, King LR, Levin LS. Use of the expanded thoracoepigastric myocutaneous flap in the closure of cloacal exstrophy. Plast Reconstr Surg 1996;97:1479-84.

6. Lewis VL Jr, Cook JQ. The nondelayed thoracoepigastric flap: Coverage of an extensive electrical burn defect of the upper extremity. Plast Reconstr Surg 1980;65:492-3. 